\title{
Harry Tzalas's Farewell to Alexandria and the Alexandrian Mime in Antiquity: The Metaphorical Language of Cultural Identity
}

\begin{abstract}
Harry Tzalas was born in Alexandria in 1936. His parents on both sides were Alexandrian-born. In 1956, he immigrated to Brazil, and he later settled in Athens. Eventually, he came to have one foot in Athens, the other in Alexandria. Accordingly, he managed to maintain his self-identity as both Greek and Alexandrian. The years he spent in Alexandria provided the stimulus to write his Farewell to Alexandria. Both Farewell to Alexandria and the ancient Alexandrian mime share the dramatization of characters and events. Their actions are located in Alexandria: one modern, the other ancient. They both contain realistic depictions of contemporary life in a cosmopolitan context. The ancient Alexandrian mime aimed to provide popular entertainment through comic dramatic scenes of everyday life in ancient cosmopolitan Alexandria. Farewell to Alexandria aims to communicate the nostalgic atmosphere of cosmopolitan Alexandria to modern readers. They both depict the ethnic diversity of people belonging to different cultures in cosmopolitan Alexandria. Each uses its own metaphorical language of cultural identity to represent life realistically in a cosmopolitan context.
\end{abstract}

Keywords: Alexandria, cosmopolitanism, cultural identity, Greeks, Herodas, metaphorical language, mime (mimiamboi), multiculturalism, multi-ethnic society, Theocritus

Harry Tzalas was born in Alexandria in $1936 .{ }^{1}$ His parents on both sides were Alexandrian-born. In 1956, he immigrated to Brazil, ${ }^{2}$ and he later settled in Athens. Eventually, he came to have one foot in Athens, the other in Alexandria. His scientific activities in underwater archaeology have mainly been devoted to Alexandria. ${ }^{3}$ Accordingly, he has managed to maintain his self-identity as both Greek and Alexandrian. The years he spent in Alexandria provided the stimulus to write his Farewell to Alexandria.

1 I would like to thank the anonymous reviewers of this article for their useful comments.

2 On the departure of the Greeks from Egypt after 1956, or what the Greeks call the mass exodus, see Sakkas (2009).

3 Cf., for example, Tzalas (2010).

Ә Open Access. (c) 2021 Magda El-Nowieemy, published by De Gruyter. (c) BY-NC-ND This work is licensed under the Creative Commons Attribution-NonCommercial-NoDerivatives 4.0 International License. 
Before outlining the direction my argument will take, a few words have to be said about both Farewell to Alexandria and the Alexandrian mime in antiquity. ${ }^{4}$ Although they do not share the exact same content, they do have some similarities. Both Farewell to Alexandria and the ancient Alexandrian mime share the dramatization of characters and events. They were both written in a cosmopolitan Alexandrian context, and their actions are located in Alexandria: one modern, the other ancient. They both contain realistic depictions of contemporary life. The ancient Alexandrian mime is an "imitation of life." Farewell to Alexandria consists of eleven short stories of "real life."

The aim of the present study is to investigate the metaphorical language of cultural identity used in both Farewell to Alexandria and the ancient Alexandrian mime, with special reference to the visual language used to verbalize ways of thinking and the imagination, as well as to the symbolic interpretations of the Alexandrian cosmopolitan and cultural experience in each case. The term "antiquity" in my title means, in this study, the Hellenistic period, which begins with the death of Alexander the Great in 323 BC and ends with the Roman conquest of Egypt and the suicide of Cleopatra VII in 30 BC.

The literary culture which was developed in Alexandria during the reign of the first Ptolemies was so influential throughout the Greek world that the term "Alexandrian" implies a style that was characteristic of the entire Hellenistic period. The Greek culture dominated as a result of the policy of the Ptolemies. ${ }^{5}$

The uniqueness of ancient Alexandria was due to its multicultural formation as a cosmopolitan city distinct from the rest of Egypt. There was a mix of

1. Macedonians as a ruling and military class;

2. Greek immigrants who were attracted to Alexandria (there was ethnic diversity even among the Greek population: Lycians, Cretans, Syracusans, and so on);

3. various other ethnic minorities (Arabs, Indians, Ethiopians, Italians, Jews, Persians, Syrians, Babylonians, and so on); and

4. the Egyptian native population, who constituted the majority.

\footnotetext{
4 Before 1889, the genre of Alexandrian or Hellenistic mime was obscure. In 1889, the British Museum obtained the Herodas papyrus, which was first published in 1891. For the work done on the papyrus ever since, see Arnott (1971, 121-122). For the mime as a genre, see Panayotakis (2014); Rist (2016, 8-11).

5 On the Hellenocentric cultural policy of the Ptolemies, see Maehler (2006, 4-13). Maehler argues correctly that the reason for this policy was the Ptolemies' perfectly rational answer to the challenge they were faced with in Egypt. Egypt was different from the other countries that Alexander had conquered with its older, and in many ways, superior civilization, as the Greeks realized. See also Stephens (2003); Rutherford (2016, 1-22).
} 
As a result, there was a socially and ethnically divided population in Egypt in the Hellenistic period. ${ }^{6}$ The two main parts of this diversity were the Egyptians, the natives who had lived there for thousands of years, and the Greeks, who came as immigrants. The Macedonian Greek monarch had to face mainly two cultures, linked though separate. ${ }^{7}$ The literary culture of ancient Alexandria was developed in this multi-ethnic monarchical society. ${ }^{8}$ If we wish to consider the culture of everyday life as reflected in literature, the Alexandrian mime comes to the fore.

One of the most celebrated literary examples of this kind is Theocritus'9 idyll 15 , which is an urban mime written in the 270 s BC. ${ }^{10}$ The poem is entitled "Adoniazusai," which means "Women at the Festival of Adonis." The poem celebrates the Adonia festival honouring Aphrodite and Adonis ${ }^{11}$ under the auspices of Queen Arsinoe II. The aim of the poem was to highlight the royal festival; however, it also highlights Alexandria's cosmopolitanism and internationalism, and the variety of its ethnicities. ${ }^{12}$

Theocritus depicted a dramatically vivid picture of Hellenistic Alexandria by focusing on two Syracusan immigrants, Praxinoa and Gorgo, residents of Alexandria. The Hellenistic age demonstrated the mobility of women; they were allowed to attend festivals with no restrictions on them, as we can see in this literary example. ${ }^{13}$ Idyll 15 starts with Gorgo paying a visit to Praxinoa's house

6 See Gruen (1993, 2).

7 See Koenen (1993).

8 As Burton $(1995,2)$ states, in the Hellenistic age, the trend of migration toward cultural and economic centres caused an increasing cosmopolitanism and internationalism of these centres: Alexandria, Antioch, and Pergamon, for example, were cosmopolitan cities. On the nature of ethnicity in Alexandria, see Delia (1996, 41-47); Erskine (2005, 12); Stephens (2010, 47-49).

9 Theocritus was a Greek poet who was born c. 300 BC in Syracuse (Sicily) and died after 260 BC. 10 Helmbold $(1951,17)$ remarks that this poem received the honour of a translation by Matthew Arnold, which is enough to make any verse proud. Some of Theocritus' idylls are indebted to the mime genre in form and theme. Poem 15 is one of these (as well as 2 and 14). On the classification of Theocritus' poems, see Hutchinson (1988, 143-147). On Theocritus' rustic idylls, which comprise most of his corpus, see Gutzwiller (1991).

11 On the time of the festival, see Helmbold $(1951,17)$.

12 See Rowlandson $(2005,253)$, who argues that a sense of the unusually dense and cosmopolitan character of life in the city is best conveyed by Theocritus' idyll 15. For the importance of idyll 15, see Hunter (2005, 483-484); Gutzwiller (2007, 92); and, differently, Delia (1996, 41-53).

13 For the idea of mobility, see Burton (1995, ch. 1); Vlassopoulos (2013, 85-94). On the liberty and autonomy enjoyed by women in Hellenistic Alexandria, see Konstan (1989, 279-281); Gutzwiller (2007, 195-200). In the words of Fantham et al. (1994, 136), "the Hellenistic is the only period in Greek and Roman history defined by the reign of a woman." 
on the outskirts of Alexandria. Gorgo presents a vivid portrait of the crowded streets by saying: ${ }^{14}$

O what a silly I was to come! What with the crush and the horses, Praxinoa, I have scarcely got here alive.

It's all big boots and people in uniform. And the street was never-ending, and you can't think how far your house is along it. (Theocritus 1996, 177)

The two women, accompanied by their slave servants, set out on their way to the palace to attend the festival of Adonis sponsored by the Queen. ${ }^{15}$ They make their way through the overcrowded streets of Alexandria. Conscious of her cultural identity and self-identity, Praxinoa abuses the Egyptians:

\footnotetext{
I must say, you've done us many a good turn, my good Ptolemy, since your father went to heaven. We have no villains sneaking up to murder us in the streets nowadays in the good old Egyptian style. They don't play those awful games now - the thorough-paced rogues, every one of them the same, all queer! (Theocritus 1996, 183)
}

Praxinoa distinguishes herself and her countrymen, the colonialists one might say, from the Egyptians, the natives of the country, by her language of abuse. ${ }^{16}$

When the two women come close to the palace, Gorgo asks an old woman they meet there about getting in; the old woman answers: "Trying took Troy, my pretty; don't they say / where there's a will there's a way?” (Theocritus 1996, 185). Praxinoa wittily adds that women know everything - even how the god Zeus married the goddess Hera. This reference to the Greek mythological and religious tradition helps enhance the Greeks' cultural identity in the cosmopolitan city of Alexandria.

14 Burton $(1995,11)$ points out that, through Gorgo's description of her experiences on the road, the poet explores her sense of alienation and disorientation in a crowded, public setting.

15 Too $(1998,118)$ discusses, in terms of the contrast between high and low, the visit of the two bourgeois women to the royal palace and their somewhat hesitant encounter with literary and visual culture there.

16 Burton $(1995,14)$ comments on this passage by saying that immigrant Greek women can (temporarily) suppress feelings of alienation and insignificance by elevating themselves as "colonials" over natives. Stephens $(2010,59)$, too, points out that, in this passage, the Egyptian population is kept at a distance and referred to as an underclass. On the Egyptian reaction to the Hellenocentric attitude of the immigrants, see Maehler (2006, 3-4). 
Another scene in the same poem illustrates how ordinary women enjoyed the freedom to move about in the streets of Alexandria and to talk to male strangers in public. ${ }^{17}$ The poet highlights the noticeably Doric accent of the two women in the context of multilingual Alexandria. A bystander mocks their way of speech, which was characteristic of their native dialect:

Oh dear, oh dear, ladies! Do stop that eternal cooing. (to the bystanders) They'll weary me to death with their ah-ah-ah-ing. (Theocritus 1996, 189)

When the two women are criticized for their accent, they defend their right as free citizens to "speak Peloponnesian." This means that these two immigrants pride themselves on being Syracusans. ${ }^{18}$ Cultural defensiveness is implied in their words.

It is more to the point if we take another example, this time from the first mime of the Alexandrian poet Herodas, ${ }^{19}$ whose mimes are considered our best evidence for the form of the mime genre. ${ }^{20}$ It is noticeable that women play a large role in the mimes of Herodas. The poet depicts Metriche, whose lover Mandris is absent in Egypt. Her old nurse, Gyllis, visits her to convince her to put aside her thoughts of her lover before old age comes over her. ${ }^{21}$ The poet states the following about Egypt through the mouth of Gyllis: ${ }^{22}$

17 See above, n. 13.

18 Clarysse $(1998,6)$ comments on this passage, explaining that speaking in dialect was a normal phenomenon in third-century Alexandria that showed one's roots in the old Greek world. See Stephens $(2010,47)$, who states that, under the early Ptolemies, there was as yet no pervasive sense of Alexandrian identity. Later on, in the second century BC, the elites were identified with Alexandria; see Rowlandson (2005, 253).

19 Herodas flourished in Alexandria in the third century BC. He is also called Herondas and Herodes. In this article, I use the Doric form of the name, Herodas; see Arnott (1971, 121n1). Herodas' seven complete poems and the fragmentary eighth are mimiamboi, that is, iambic mimes, or mimes written in the iambic metre associated with invective poetry; see Konstan (1989, 267). For the term mimiamboi, see Cunningham (1966, 1n1).

20 As Esposito $(2010,267)$ puts it: "Herodas can be considered the most representative exponent of literary mime of the Hellenistic era.” On the dramatic vigour of Herodas' mimes, see Rist (2016, 21-23).

21 See the discussion of Fountoulakis $(2002,305,309)$ on the motif of women visiting each other as related to New Comedy.

22 Cos is a possible birthplace of Herodas. However, as Fountoulakis (2002, 316n82) remarks, the evidence concerning his birthplace as well as the place where he lived is still inconclusive. Herodas lived and wrote at the time of Callimachus and Theocritus, that is, the third century BC. Arnott $(1971,122)$ points out that Herodas lived and wrote, if not in Alexandria, then at least somewhere in that part of the ancient world. In Hutchinson's view $(1988,236 n 36)$, the praise of Egypt in his first poem "associates the poet with country and king." 


\begin{abstract}
Well, my child, how long now is it that you've been separated, wearing out your single bed alone? It's ten months since Mandris set off for Egypt, and not a word does he send you; he has forgotten and drunk from a new cup. The home of the goddess is there. For everything in the world that exists and is produced is in Egypt: wealth, wrestling schools, power, tranquility, fame, spectacles, philosophers, gold, youths, the sanctuary of the sibling gods, the King excellent, the Museum, wine, every good thing he could desire, women as many by Hades' Maid as the stars that heaven boasts of bearing and as lovely as [the goddesses] who once hastened to Paris to be [judged] for beauty - may they not notice [what I Say]! (Herodas 1993, 221-223)
\end{abstract}

The subtle insights of Herodas are best displayed in his characterization and the language that suits the characters, or what is called "characterization by language." ${ }^{23}$ Through the words of Gyllis, who is an ordinary lower-class character, ${ }^{24}$ the poet refers to the elements that constitute the cultural identity of ancient Alexandria. She presents a picture of contemporary life in Alexandria that includes the cultural, political, and religious characteristics as well as the pleasures of Alexandria. ${ }^{25}$ Among the notable attractions of Alexandria, it does not escape Gyllis to mention the "Museum." ${ }^{26}$ The attractions of Alexandria which tempted Mandris were meant to be the same as those that attracted Greeks in general to immigrate to Alexandria in the Hellenistic age. The poet uses the lively language of the proverbs and commonly used expressions of the uneducated classes among the Greeks. ${ }^{27}$

23 Ussher $(1980,71)$ comments on Herodas' characters by saying that they are real people, captured in real moments of existence, and drawn with psychological perceptiveness. Ussher (1985, 67-68) also argues that among the most vital and real of ancient characters (particularly, of ancient female characters) are those of Herodas' mimiamboi. See the discussions by Arnott (1971, 125, 128-129) on the "mosaic technique" by which Herodas' characters are built up, and the power of Herodas' characterization in most of his extant work.

24 Too $(1998,118)$ stresses the contrast between Alexandrian society and the two uneducated women, inhabitants of some inconspicuous town.

25 As Hutchinson $(1988,254)$ points out, there is some dignity in the praise of Egypt (Herodas 1993, 11. 25-35).

26 Critics have noticed that this is the earliest reference to the Mouseion of Alexandria; see, for example, Ussher (1980, 71; 1985, 50).

27 On the linguistic features of Herodas, see Fountoulakis (2002, 309). For Herodas' use of proverbs and related figures of speech, see Arnott (1971), who rightly notes that Herodas' main pur- 
It is worth noting that the modern Alexandrian poet Constantine P. Cavafy (1863-1933), who was well versed about the classical world, had a special interest in the mimes of Herodas. His posthumously published poem entitled "The Mimiambi of Herodas" was written on the occasion of the discovery of a fragmented papyrus of Herodas in the sands of Egypt. ${ }^{28}$ Cavafy points to the event in the first two stanzas of his poem, and then he portrays scenes from the papyrus. ${ }^{29}$ Cavafy's poem reflects his sense of the literary past, which is contained in the general framework of his perspective on history. ${ }^{30}$ We cannot go so far as to suggest a connection between Cavafy's poem and Harry Tzalas's Farewell to Alexandria. It is a remarkable coincidence, but not a case of influence or inspiration. ${ }^{31}$

It is apparent that Tzalas, in his Farewell to Alexandria, is fully aware of the significance of very many details regarding the cultural reality of Alexandria in the 1940s and 1950s. His focal point is exclusively Alexandria. Those who used to be on the margins of Alexandrian society in the mid-twentieth century, like workmen, porters, office-boys, and middle-class citizens, move to the centre of some of Tzalas's short stories. Tzalas depicts the ethnic diversity of cosmopolitan Alexandria. ${ }^{32}$ He bridges the distance between people originally belonging to different cultures: Arabic-speaking Egyptians, both Copts and Muslims, and members of cosmopolitan society: Greeks, Italians, Jews, Armenians, Syrians, Slavs, and Maltese, as well as French, English, and Germans.

One of Tzalas's short stories is entitled: "Alexandrea ad Aegyptum." 33 This is the way Alexandria was historically referred to - "Alexandria by Egypt" or

pose with this technique was to imitate life and to remind his Hellenistic audiences of the way that uneducated Greeks actually spoke.

28 See above, n. 4. Herodas' text is based on this single papyrus from the second century AD, which was published in 1891 . See Jusdanis $(1987,139)$. On the discovery of the Herodas papyrus, see Esposito (2010, 268).

29 For an English translation of Cavafy's poem, see Cavafy and Dalven (1972).

30 In the words of Faubion (2003, 42): “Cavafy does not report history, he picks it, one fruit at a time from a neglected orchard.” For a post-colonial analysis of Cavafy's poem, see Halim (2013, 77-78).

31 My assertion is based on a recent conversation with Harry Tzalas, who confirmed that he has not read Cavafy's poem, and was not inspired in any way by it.

32 See Mabro (2006, 247-262); Abou-Ayana (2014). On the nature of Alexandrian society from the mid-nineteenth to the mid-twentieth century, and the significant and dramatic change in its ethnic composition, see Fahmy (2006a).

33 The Farewell to Alexandria collection of short stories was first published in Greek (1997) under the title Alexandrea ad Aegyptum. 
"next to Egypt” (and not "in Egypt"). ${ }^{34}$ The main character in Tzalas's story was a Frenchman, Dr Tawa, resident in Alexandria. Tzalas said about him:

Docteur Tawa spoke all the languages that one might hope to hear in cosmopolitan Alexandria in the middle of the twentieth century. It was not uncommon to find people who were multi-lingual in those days in Alexandria - apart from their own mother tongue, most people could converse in several other languages. (Tzalas 2004, 151-152)

Alexandria was alive in Dr Tawa's heart, as reflected in the following words: "Alexandria is resurrected for all those who called her Utopia, who have loved her and lost her, the Alexandria of children and poets" (Tzalas 2004, 162).

Tzalas, like other Greeks who lived in Alexandria and left her, presents with a sense of loss an account of the city's European culture, which has been called "a cosmopolitan culture." 35 This cosmopolitan society, in Tzalas's view, was mainly linked to the presence of Europeans and other non-Egyptians. ${ }^{36}$ He communicated this idea in another short story, "Frau Grete," by saying: "So Alexandria, a cosmopolitan city since its very foundation, suddenly found herself inhabited only by Egyptians. The city to which the poet had prophetically bid farewell fifty years before was vanishing forever. One after the other, we all bid our own farewells" (Tzalas 2004, 56).

From the early nineteenth century, the Greeks were the most notable community of all foreigners in Egypt. ${ }^{37}$ They had a special relationship with Egypt. Farewell to Alexandria is not only a sort of nostalgic literature; ${ }^{38}$ it also holds a mirror to Alexandria society at the time: its culture, its composition, and the relationship between its parts. Tzalas also introduces into the present-day Alexandrian imagination the possibility of a different society with an enhanced role for both coexistence and interaction, developed on the model of ancient Alexandria.

34 For a discussion of the term "Alexandria by Egypt," see Green (1996, 3), who considers that one of the factors encouraging mythicization of the city of Alexandria has always been Alexandria's more-than-symbolic separation from Egypt. See also Meskens (2010, ch. 2). The term "Alexandria by Egypt" is not disputed; however, Fraser $(1949,56)$ discusses a piece of evidence from the third century BC showing that, in circles closely connected with Alexandria, the city was thought of as "in Egypt." See also Fahmy (2006b), who argues in favour of "Alexandria in Aegypto.” See also Kararah (2006).

35 See, among others, Kitroeff (1983), who presents an account of certain aspects of life in Alexandria from the late nineteenth century to the mid-twentieth century with a noticeable sense of loss.

36 For an interesting and insightful analysis of Alexandrian cosmopolitanism with a post-colonial perspective, see Halim (2013).

37 The modern Greek presence in Egypt began during the era of Muhammad Ali (1805-1849).

38 For a further nostalgic Alexandrian voice, see Tzalas (2009). 
To conclude, two notable periods in the long history of Alexandria have been referred to in this article: one ancient (the first three centuries before our common era), the other modern (around the mid-twentieth century). In each case, Alexandria attracted people from all over the Mediterranean and from elsewhere, many of whom made her their place of residence.

To explore the nature of Alexandrian society, and the nature of its cultural identity, we have to look at the ethnic composition of the city. In each of the two periods, this society peacefully enjoyed cultural prosperity, depending on either the coexistence of or interaction between different ethnicities, and developed into a cosmopolitan society. The cultural identity of this society depended in each of the two periods on different geographical backgrounds, different languages, and different religious beliefs.

In spite of the resemblances between Farewell to Alexandria and the Alexandrian mime of antiquity, each uses its own metaphorical language of cultural identity in its own way, yet with the same purpose: to represent life in a cosmopolitan context realistically. This cosmopolitan society of Alexandria is the subject of both the ancient Alexandrian mime and Farewell to Alexandria. But Farewell to Alexandria is the epilogue to Alexandrian cosmopolitanism. The narrative voice of the author arises with a hint of goodbye to cosmopolitan Alexandria. The cosmopolitan cultural identity has been replaced by a national identity since the rise of the Egyptian nationalism in the 1950s. ${ }^{39}$

\section{Works cited}

Abou-Ayana, Fathy M. "Italians in Modern Alexandria." Papyri 3 (2014): 1-10.

Arnott, W. Geoffrey. “Herodas and the Kitchen Sink.” Greece \& Rome 18.2 (1971): 121-132.

Burton, Joan B. Theocritus's Urban Mimes: Mobility, Gender, and Patronage. Berkeley:

University of California Press, 1995.

Cavafy, C. P., and Rae Dalven. "The Mimiambi of Herodas." Poetry 120.5 (1972): 258-259.

Clarysse, Willy. "Ethnic Diversity and Dialect among the Greeks of Hellenistic Egypt." The Two

Faces of Graeco-Roman Egypt. Ed. A. Verhoogt and S. Vleeming. Leiden: Brill, 1998. 1-13.

Cunningham, I. C. "Herodas 4." Classical Quarterly 16.1 (1966): 113-125.

Delia, Diana. “All Army Boots and Uniforms? Ethnicity in Ptolemaic Egypt.” Alexandria and

Alexandrianism: Papers Delivered at a Symposium Organized by The J. Paul Getty Museum and The Getty Center for the History of Art and the Humanities. Malibu: The J. Paul Getty Museum, 1996. 41-53.

39 For another perspective on the cultural identity of modern Egypt, see El-Nowieemy (2016, 13-14). 
El-Nowieemy, Magda. "Longing and Belonging: An Egyptian Cultural Perspective of Medi terraneanism.” Scientific Culture 2.3 (2016): 11-15. https://sci-cult.com/longing-andbelonging-an-egyptian-cultural-perspective-of-mediterraneanism/ (10 August 2018).

Erskine, Andrew. "Approaching the Hellenistic World." A Companion to the Hellenistic World. Ed. Erskine. Malden and Oxford: Blackwell, 2005.1-15.

Esposito, Elena. "Herodas and the Mime." A Companion to Hellenistic Literature. Ed. James J. Clauss and Martine Cuypers. Oxford and Malden: Wiley-Blackwell, 2010. 267-281.

Fahmy, Khaled. "For Cavafy, with Love and Squalor: Some Critical Notes on the History and Historiography of Modern Alexandria." Alexandria Real and Imagined. Ed. Anthony Hirst and Michael Silk. Cairo: The American University in Cairo Press, 2006a. 263-280.

Fahmy, Khaled. "Towards a Social History of Modern Alexandria." Alexandria Real and Imagined. Ed. Anthony Hirst and Michael Silk. Cairo: The American University in Cairo Press, 2006b. 281-306.

Fantham, Elaine, Helene Peet Foley, Natalie Boymel Kampen, Sarah B. Pomeroy, and H. Alan Shapiro. Women in the Classical World: Image and Text. Oxford: Oxford University Press, 1994.

Faubion, James D. "Cavafy: Toward the Principles of a Transcultural Sociology of Minor Literature." Modern Greek Studies 11 (2003): 40-65.

Fountoulakis, Andreas. "Herondas 8.66-79: Generic Self-Consciousness and Artistic Claims in Herondas' Mimiambs." Mnemosyne 55.3 (2002): 301-319.

Fraser, P. M. "Alexandria ad Aegyptum Again.” Journal of Roman Studies 39.1-2 (1949): 56.

Green, P. "Alexander's Alexandria." Alexandria and Alexandrianism: Papers Delivered at a Symposium Organized by The J. Paul Getty Museum and The Getty Center for the History of Art and the Humanities. Malibu: The J. Paul Getty Museum, 1996. 3-25.

Gruen, Erich S. "Cultural Fictions and Cultural Identity." Transactions of the American Philological Association 123 (1993): 1-14.

Gutzwiller, Kathryn J. Theocritus' Pastoral Analogies: The Formation of a Genre. Madison: University of Wisconsin Press, 1991.

Gutzwiller, Kathryn J. A Guide to Hellenistic Literature. Malden and Oxford: Blackwell Publishing, 2007.

Halim, Hala. Alexandrian Cosmopolitanism: An Archive. New York: Fordham University Press, 2013.

Helmbold, W. C. “The Song of the Argive Woman's Daughter.” Classical Philology 46.1 (1951): 17-24.

Herodas. "Herodas: Mimes." Theophrastus, Characters; Herodas, Mimes; Cercidas and the Choliambic Poets. Ed. and trans. J. Rusten, I. C. Cunningham, and A. D. Knox. Cambridge and London: Harvard University Press, 1993. 199-317.

Hunter, Richard. "Literature and Its Contexts." A Companion to the Hellenistic World. Ed. Andrew Erskine. Malden and Oxford: Blackwell, 2005. 477-493.

Hutchinson, G. O. Hellenistic Poetry. Oxford: Clarendon Press, 1988.

Jusdanis, Gregory. Cavafy: Textuality, Eroticism, History. Princeton: Princeton University Press, 1987.

Kararah, Azza. "Egyptian Literary Images of Alexandria.” Alexandria Real and Imagined. Ed. Anthony Hirst and Michael Silk. Cairo: The American University in Cairo Press, 2006. 307-321.

Kitroeff, Alexander. “The Alexandria We Have Lost.” Journal of the Hellenic Diaspora 10.1-2 (1983): 11-21. 
Koenen, Ludwig. “The Ptolemaic King as a Religious Figure." Images and Ideologies:

Self-Definition in the Hellenistic World. Ed. Anthony W. Bulloch, Erich S. Gruen, A. A. Long, and Andrew Stewart. Berkeley and Los Angeles: University of California Press, 1993. 25-115.

Konstan, David. “The Tyrant Goddess: Herodas’s Fifth Mime.” Classical Antiquity 8.2 (1989): 267-282.

Mabro, Robert. "Alexandria 1860-1960: The Cosmopolitan Identity." Alexandria Real and Imagined. Ed. Anthony Hirst and Michael Silk. Cairo: The American University in Cairo Press, 2006. 247-262.

Maehler, Herwig. "Alexandria, the Mouseion, and Cultural Identity." Alexandria Real and Imagined. Ed. Anthony Hirst and Michael Silk. Cairo: The American University in Cairo Press, 2006. 1-14.

Meskens, A. Travelling Mathematics: The Fate of Diophantos' Arithmetic. Basle: Springer Basel Ag, 2010. Science Networks Historical Studies 41.

Panayotakis, Costas. "Hellenistic Mime and Its Reception in Rome." The Oxford Handbook of Greek and Roman Comedy. Ed. Michael Fontaine and Adele C. Scafuro. Oxford: Oxford University Press, 2014. 378-396.

Rist, Anna, trans. and introd. The Mimiambs of Herodas. London and New York: Bloomsbury Academic, 2016.

Rowlandson, Jane. "Town and Country in Ptolemaic Egypt." A Companion to the Hellenistic World. Ed. Andrew Erskine. Malden and Oxford Blackwell, 2005. 249-263.

Rutherford, Ian. "Introduction: Interaction and Translation between Greek Literature and Egypt.” Greco-Egyptian Interactions: Literature, Translation, and Culture, 500 BCE-300 CE. Ed. Rutherford. Oxford: Oxford University Press, 2016. 1-39.

Sakkas, John. "Greece and the Mass Exodus of the Egyptian Greeks, 1956-66." Journal of the Hellenic Diaspora 35.2 (2009): 101-117.

Stephens, Susan. Seeing Double: Intercultural Poetics in Ptolemaic Alexandria. Berkeley: University of California Press, 2003.

Stephens, Susan. "Ptolemaic Alexandria." A Companion to Hellenistic Literature. Ed. James J. Clauss and Martine Cuypers. Malden and Oxford: Wiley-Blackwell, 2010. 46-61.

Theocritus. In The Greek Bucolic Poets. Trans. J. M. Edmonds. Cambridge: Harvard University Press, 1996. 5-585

Too, Yun Lee. The Idea of Ancient Literary Criticism. Oxford: Clarendon Press, 1998.

Tzalas, Harry E. Farewell to Alexandria. Trans. Susan E. Mantouvalou. Cairo: The American University in Cairo Press, 2004.

Tzalas, Harry E. Seven Days at the Cecil. Trans. Susan E. Mantouvalou. Alexandria: Bibliotheca Alexandrina, 2009.

Tzalas, Harry E. "The Underwater Archaeological Survey of the Greek Mission in the Coastal Area of Ramleh, Alexandria, Egypt (1998-2009)." First Hellenistic Studies Workshop: Proceedings. Ed. Kyriakos Savvopoulos. Alexandria: Alexandria Center for Hellenistic Studies, 2010. 56-63.

Ussher, Robert G. "The Mimiamboi of Herodas.” Hermathena 129 (1980): 65-76.

Ussher, Robert G. "The Mimic Tradition of 'Character' in Herodas." Quaderni Urbinati di Cultura Classica 21.3 (1985): 45-68.

Vlassopoulos, Kostas. Greeks and Barbarians. Cambridge: Cambridge University Press, 2013. 
Magda El-Nowieemy is Professor of Greco-Roman Studies at the Faculty of Arts, Alexandria University. She has focused her research on Latin literature, and has published a number of papers in the field. Her research interests include ancient Greek, Hellenistic, and Roman cultures; Augustan Latin poetry; the reception of the Greco-Roman classics, especially in the Arab World; comparative literature; and cultural studies. 